\title{
Mindfulness-Based Cognitive Therapy in Major depressive disorder - systematic review and metanalysis
}

\author{
Relação entre a Mindfulness-Based Cognitive Therapy \\ e seu efeito no transtorno depressivo maior
}

Rafaela Liberali*

Universidade Federal de Santa Catarina (UFSC), Florianópolis, SC, Brazil

\begin{abstract}
Introduction: MBCT practices increases the ability of concentration and attention, as well is particularly effective for people with current and treatment-resistant depression. Objective: To analyze the effects of the application of MBCT in symptoms of MDD. Methods: systematic review and meta-analysis. To find suitable studies, we searched PubMed/MEDLINE's database using the keywords mindfulness and major depressive disorder. Studies in English published between 2003 and 2015 were selected. The studies were evaluated according to their methodological quality by PEDro scale (score greater than 3), studies that showed empirical evidence, had an experimental study design (randomized and non-randomized), and whose full text was available. For the meta-analysis, we used a random-effects model with standardized mean differences and 95\% confidence intervals. Results: Fourteen es were included, of which three were non-randomized, with only one group with intervention of MBCT, and 11 were randomized studies, divided into two-group samples and three-group samples. The non-randomized studies showed a PEDro score of 5, while the twogroup and three-group randomized studies showed PEDro scores of 5-10 and 6-9, respectively. In the metaanalysis, the four randomized studies selected revealed a moderate effect of MBCT on the outcome of depression symptoms, with a mean difference of -0.52 (95\% CI: -1.050 to $-0.002 ; p=0.04)$. Conclusion: The MBCT presented as a promising alternative for the treatment of this disorder.
\end{abstract}

Keywords: Mindfulness. Depression. Behavior Therapy. Depressive Disorder Major.

\footnotetext{
* RL: Doctoral student, e-mail: rafaelametodologia@gmail.com
} 
Introdução: MBCT práticas aumenta a capacidade de concentração e de atenção, assim é particularmente eficaz para as pessoas com depressão recorrente e resistentes ao tratamento. Objetivo: analisar os efeitos da aplicação da MBCT nos sintomas do Transtorno Depressivo Maior (TDM). Metódos: Revisão sistemática e metanálise. Utilizou-se para a busca dos estudos, a base de dados MEDLINE (PubMed), com os descritores mindfulness e major depressive disorder. Selecionaram-se artigos na língua inglesa entre os anos de 2003 a 2015. Os estudos foram avaliados quanto sua qualidade metodológica pela escala Pedro (pontuação maior que 3), que demonstrassem evidência empírica, com design de estudo experimental (randomizado e não randomizado) $e$ estar disponível na íntegra. Para a metanálise utilizou-se modelo de efeitos aleatórios com diferenças médias padronizadas e intervalos de confiança de 95\%. Resultados: Quatorze estudos foram incluídos, sendo 03 não randomizados, contendo apenas um grupo de intervenção da MBCT e 11 estudos randomizados, divididos em amostras de dois grupos e amostras de três grupos. Os estudos não randomizados apresentaram escala Pedro de 5 pontos, os randomizados de dois grupos (de 5 a 10 pontos) e de três grupos (de 6 a 9 pontos). Na metanálise os quatro 4 estudos randomizados selecionados, revelaram um efeito moderado da MBCT sobre o desfecho dos sintomas da depressão, com uma diferença média de -0.52 (IC 95\%: -1.050 a -0.002; $p=0.04$ ). Conclusão: A MBCT apresenta-se como uma alternativa promissora para tratamento desse transtorno.

Palavras-Chave: Meditação. Depressão. Terapia Comportamental. Transtorno Depressivo Maior.

\section{Introduction}

Major depressive disorder (MDD) is a complex disease with patterns of persistence, remission and relapse, which presents a likelihood of recurrence greater than $80 \%(1,2)$. It has a global prevalence of $16 \%$ and it is estimated that it will be the second most prevalent illness by 2020 , with an increase of $6.2 \%$ by $2030(3,4)$. It presents different prevalence rates among countries, $1.5 \%$ in Taiwan, $7.0 \%$ in South Korea, 19\% in Lebanon, 9.2\% in Germany, 9\% in Chile (5), $3 \%$ to $54 \%$ in Africa (6), $6.4 \%$ to $16 \%$ in the USA $(4,7)$ and $2.7 \%$ in Thailand (8).

It is characterized by psychological, physical and behavioral symptoms, mainly including depressed mood, loss of energy, suicidal tendencies and decreases in interest, cognition, quality of life and academic or occupational functioning (9 - 11). Although psychological interventions are effective in the treatment of MDD, the prescription of antidepressant drugs is the mainstay of treatment to prevent relapse and recurrence (12), however, this may present some limitations, such as poor adherence and side effects (13).

Because of these limitations, some nonpharmacological alternatives have been implemented, includinginterventions in lifestyle, behaviormodification, counseling and psychological therapies $(13,14)$. One of these therapies is meditation, which is currently being integrated into the clinical practice for some medical conditions, such as hypertension, cancer, chronic pain, diabetes, etc. $(15,16)$ and psychiatric conditions, such as anxiety, suicidal tendencies, obsessive-compulsive disorder, personality disorders and especially for depression $(17,18)$.

Approximately 25 years ago, Jon Kabat-Zinn incorporated meditation (dating back more than 5,000 years) into medical practice, implementing the Mindfulness-Based Stress Reduction (MBSR) program, which is an adaptation of Buddhist techniques for stress reduction (19-21). Today, there is a range of therapeutic approaches based on mindfulness, such as Mindfulness-Based Eating Awareness Training, Mindfulness-Based Relationship Enhancement, Mindfulness-Based Relapse Prevention and Mindfulness-Based Cognitive Therapy (MBCT) (22).

Mindfulness-Based Cognitive Therapy (MBCT) is a group therapy with 10 to 15 participants held over 6 to 8 weeks, created specifically to help manage stress and depressive symptoms $(23,24)$. It is recommended by the National Institute for Health and Clinical Excellence, in the UK, as a medical treatment for people with recurrent depression $(25,26)$.

The benefits of this meditation can be associated with improvement in cognitive control, regulation of the emotions, positive mood and acceptance (27), 
as it aims to teach patients to relate to unpleasant thoughts, feelings and bodily sensations. Therefore, it seems reasonable to assume that the practice can mitigate the symptoms of depression. Thus, the aim of this study was to analyze, through a systematic review and meta-analysis, the effects of the application of MBCT on symptoms of MDD.

\section{Methods}

Studies were identified using the US National Library of Medicine - National Institutes of Health MEDLINE (PubMed/PMC) database. The procedures related to searching the database complied with the following steps:

First step - identification of descriptors controlled by the MeSH (Medical Subject Headings): 'Breast Cancer' and not controlled 'MBSR mindfulness-based stress reduction'.

The choice of articles for the construction of this study was based on the proposal of Cook and West (28) in which the process of inclusion/ exclusion of studies typically has two phases: - In phase 1 , only the title, abstract and keywords are examined. During this phase if the item is ineligible, based on the title and abstract, it is excluded. If there is any doubt, as in one case where the abstract contained insufficient information, the analysis of the article advances to phase 2 ; - In phase 2 , the full text of each article is read to take the final inclusion/exclusion decision (Figure 1).

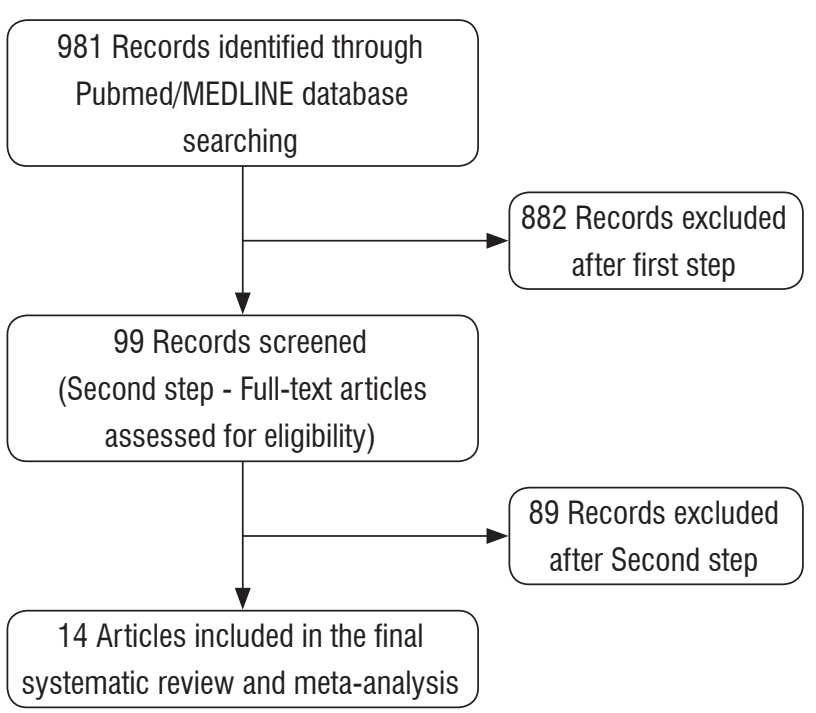

Figure 1 -Flow diagram of search.
The methodological quality of all studies was assessed using the PEDro scale (29). The Physiotherapy Evidence Database (PEDro; http://www.pedro.org.au) is a free database of randomized controlled trials (RCTs), systematic reviews and clinical practice guidelines in physiotherapy. The PEDro scale is based on the Delphi list developed by Verhagen and colleagues at the Department of Epidemiology, University of Maastricht. The purpose of the PEDro scale is to help the users of the PEDro database rapidly identify which of the known or suspected randomized clinical trials (i.e. RCTs or CCTs) archived on the PEDro database are likely to be internally valid (criteria 2 - 9), and could have sufficient statistical information to make their results interpretable (criteria 10 -11).

We excluded trials if interventions in the MDD contained other therapies, only accepted MindfulnessBased Cognitive Therapy, as they did not match the scope of this study.

\section{Data Analysis}

The Stata software (version 12.0; Stata Corp., College Station, USA) was used for data synthesis and analysis. A meta-analysis of four studies classified as randomized was conducted, as these presented depression scores in continuous data. Using the random effects and combined effects model the mean standardized differences with $95 \%$ confidence intervals were reported. All the studies had to compare the effect of MBCT with other intervention groups over a standard period of 8 weeks.

Heterogeneity between the results of the studies was assessed using the Cochran Q test and I2 statistic, which defines $0 \%$ as absence of heterogeneity, $25 \%$ as low, $50 \%$ as moderate and $\geq 75 \%$ as high heterogeneity (30). P values $\leq 0.05$ were considered statistically significant. The forest plot graph was used to detect any publication bias and the respective 95\% CI of each study.

In order to investigate the effectiveness of the MBCT, the effect size of the difference in improvement and/ or reduction of the depressive symptoms of the mean of the experimental and control groups was evaluated. Cohen's $d$ was used for the calculation of the effect size, correcting the bias when the sample size was different using Hedges'g (31). According to the classification, 0.20 $\leq \mathrm{d}<0.50$ was considered an indicator of small, $0.50 \leq$ $\mathrm{d}<0.80$ medium and $\mathrm{d} \geq 0.80$ large effect size. 


\section{Results}

The search located 981 studies in the PubMed/ MEDLINE database, with the descriptors 'mindfulness-based cognitive therapy' AND 'major depressive disorder', of these, 14 studies were selected for analysis, due to fulfilling the inclusion criteria (Figure 1).

For a description of the studies in the tables, the following categories were considered: the year of publication, where the study was conducted, classification on the Pedro scale, scales used as measuring instruments, publishing journal, sample (age group and gender), intervention (mindfulness and other psychological approaches), monitoring of the sample and results obtained (Table 1 and 2).

The countries where the studies were developed were mainly distributed between the USA and Europe, with one in Iran. The publication of the articles occurred between the years 2006 [1 (7.14\%)], 2007 [1 (7.14\%)], 2009 [1 (7.14\%)], 2010 [2 (14.28\%)], 2012 [1 (7.14\%)], 2013 [3 (28.6\%)], 2014 [2 (14.28\%)], and 2015 [2 (14.28\%)]. The scales used in the studies are shown in Table 1 , with the BDI-II = Beck Depression Inventory-II being the scale most used [05 (41.66\%)].

Table 1 - Characteristics of the included studies

\begin{tabular}{|c|c|c|c|c|}
\hline Studies & Years & Studies Local & Questionnaire & Journals \\
\hline Finucane e Merce (32) & 2006 & $\begin{array}{l}\text { Ayrshire, Scotland University of Glasgow } \\
\text { (EUA) }\end{array}$ & BDI-II, BAI & BMC Psychiatry \\
\hline Kenny e Willians (33) & 2007 & Queen Elizabeth Hospital (UK) & BDI & $\begin{array}{l}\text { Behaviour Research } \\
\text { and Therapy }\end{array}$ \\
\hline Barnhofer et al.(34) & 2009 & $\begin{array}{l}\text { Department of Psychiatry, Warneford } \\
\text { Hospital (UK) }\end{array}$ & BDI-II; BSS & $\begin{array}{l}\text { Behaviour Research } \\
\text { and Therapy }\end{array}$ \\
\hline Bondolfi et al. (35) & 2010 & $\begin{array}{l}\text { Geneva e Lausanne University Hospitals } \\
\text { (Suíça) }\end{array}$ & MADRS; HAM-D 17 & $\begin{array}{l}\text { Journal of Affective } \\
\text { Disorders }\end{array}$ \\
\hline Segal et al. (36) & 2010 & $\begin{array}{l}\text { Centre for Addiction and Mental Health } \\
\text { (CAMH), Toronto and St. Joseph's } \\
\text { Healthcare, Hamilton }\end{array}$ & HAM-D 17 & Arch Gen Psychiatry \\
\hline Bieling et al. (42) & 2012 & $\begin{array}{l}\text { Centre for Addiction and Mental Health } \\
\text { (CAMH), Toronto and St. Joseph's } \\
\text { Healthcare, Hamilton }\end{array}$ & HRSD & $\begin{array}{l}\text { Journal of Consulting } \\
\text { and Clinical Psychology }\end{array}$ \\
\hline Van Vugt et al. (2) & 2012 & $\begin{array}{l}\text { Department of Psychology in Tucson, } \\
\text { University of Arizona. (EUA) }\end{array}$ & $\begin{array}{l}\text { BDI; STAI-Y1, RSQ; } \\
\text { TSST }\end{array}$ & $\begin{array}{l}\text { Frontiers in Human } \\
\text { Neuroscience }\end{array}$ \\
\hline Batink et al. (43) & 2013 & Maastricht (Holanda) & HRSD; RSS & PLoS One \\
\hline Munshi et al. (37) & 2013 & $\begin{array}{l}\text { Langley Porter Psychiatric Hospital and } \\
\text { Clinics (LPPH\&C) at the University of } \\
\text { California San Francisco (EUA) }\end{array}$ & BDI-II; RRS; STAI-Y1 & Mindfulness \\
\hline Omidi et al. (38) & 2013 & $\begin{array}{l}\text { Social Welfare and Rehabilitation Sciences } \\
\text { and Tehran University Counseling Centre (Irã) }\end{array}$ & BSI & $\begin{array}{l}\text { Iran Red Crescent Med } \\
\text { Jornal }\end{array}$ \\
\hline Schoenberg e Speckens (39) & 2014 & $\begin{array}{l}\text { Radboud University Medical Centre Nijmegen } \\
\text { (Holanda) }\end{array}$ & IDS; RRS & Cogn Neurodyn \\
\hline Williams et al. (40) & 2014 & $\begin{array}{l}\text { Clinicas de saúde mental em Oxford, } \\
\text { England, and Bangor, North Wales }\end{array}$ & $\begin{array}{l}\text { BDI-II; Suicide Attempt } \\
\text { and Self-Injury Interview }\end{array}$ & $\begin{array}{l}\text { Jornal of Consuling and } \\
\text { Clinical Psychology }\end{array}$ \\
\hline Kuyken et al. (41) & 2015 & $\begin{array}{l}\text { Quatro centros de UK: Bristol, Exeter and } \\
\text { east Devon, north and mid Devon, and south } \\
\text { Devon }\end{array}$ & BDI & Lancet \\
\hline Shallcross et al. (13) & 2015 & Àrea urbana de Rocky Mountain West (EUA) & BDI-II & $\begin{array}{l}\text { Jornal of Consuling and } \\
\text { Clinical Psychology }\end{array}$ \\
\hline
\end{tabular}

Note: BAI = Beck Anxiety Inventory; BDI = Beck Depression Inventory; BDI-II = Beck Depression Inventory-II; MADRS = Escala de Classi $\square$ cação da Depressão de Montgomery (AsberMontgomery Asberg Depression Rating); HRSD = Hamilton Rating Scale for Depression; HAM-D $17=$ Escala de Hamilton para Avaliação de Depressão; STAI-Y1 = Spielberger State-Trait Anxiety Inventory form Y; RSQ = Ruminative Responses Scale; TSST = Trier Social Stress Test; BSI = Brief Symptom Inventory; IDS-SR $\geq 21$ = Inventory of Depressive Symptomatology- Self Report; RRS = Ruminative Response Scale; ICD-10 = criteria; DSM-IV-TR Axis I e II = Research Version of the Structured Clinical Interview; BSS = Beck Scale for Suicide Ideation; IDS = depressive symptom; RRS = response patterns towards feelings of sadness/depression. 
Table 1 shows that, in the majority of studies [11 out of 14 studies in Table 2 (78.58\%)] $(2,13,32,33$, $34,35,36,38,39,42,43)$ the subjects were within the age group classified as adults (18 to 64 years old) and only [3 (21.42\%)] $(37,40,41)$ used samples with older adults (18 to 84 years old).

All the studies used MBCT as the intervention, based on the Manual derived from the work of KabatZinn $(19,20)$. They performed this with people diagnosed with MDD according to the DSM-IV and were composed of mixed samples, totaling 1.416, predominantly [1.062 (75\%)] female, and [354 (25\%)] male participants.

The interventions of the studies presented different designs:

- Non-randomized studies [03 (21.42\%)], containing only one MBCT group $(32,33,37)$;

- Randomized studies [7 (50\%)] with the samples divided into two groups, comparing MBCT: with a control [2 $(2,39)]$, with usual treatment and therapy [3 $(34,35,43)]$, with medication [1 (41)] and with the focus on the four areas of nutrition, physical activity, functional movement and music therapy [ 1 (13)]; and samples divided into three groups, comparing MBCT: with medication and a placebo $[2(36,42)]$, with cognitive therapy and the treatment as usual with therapy [2 $(38,40)]$.

The scores of the Pedro scale that measures the quality of the trials ranged from 5 to 10 points (total mean of all studies $=7.1 \mathrm{SD}=1.8$ ). The nonrandomized studies presented a Pedro score of 5 points $(32,33,37)$, the randomized studies with two groups from 5 to 10 points $(2,13,34,35,39,41)$ and those with three groups from 6 to 9 points $(36,38,40)$.

The three non-randomized studies, containing only an intervention group showed the result that eight weeks of practice of MBCT led to decreases in the scores of depression $(32,33,37)$, anxiety $(32,37)$, suicidal thoughts (33) and rumination (37).

Of the randomized studies with the samples divided into two groups, the results suggest that eight weeks of practice of MBCT presented better results in the scores of the rate and time of relapse, in the delay of the change of medication and in the demand for a therapist compared with TAU. Batink et al. (43) demonstrated improvement in rumination scores in a group with $\geq 3$ depressive episodes $(\mathrm{MBCT}+\mathrm{TAU})$ and in a group with $\geq 2$ depressive episodes (TAU). In the study of Van Vugt et al. (2) practicing MBCT decreased the scores of depression and anxiety, however, both groups (MCBT and Control) increased their tendency to sustain trains of positive words.

The randomized studies with samples divided into three groups demonstrated that eight weeks of practice of MBCT presented better results regarding time of relapse than the antidepressant medication (ADM) and placebo (PLA) groups (34) and than the cognitive psychological education (CPE) and treatment as usual (TAU) groups (40); being better than $\mathrm{m}$-ADM and PLA (36) regarding the days to achieve remission. In the study by Bieling et al. (42) the MBCT, m-ADM and PLA groups did not show improvements in rumination, however the MBCT group improved the ability of the subjects to monitor and observe their thoughts and feelings. Conversely, in the study by Williams et al. (40) the CPE group showed better results related to more time before seeking a therapist and the use of new depressive medication than the MBCT and TAU groups. Omidi et al. (38) showed similar results among the groups, with a decrease in depression and anxiety scores mainly in the MBCT group followed by the cognitive based therapy (CBT) and TAU groups.

Table 2 - Characteristics of the studies Interventions

\begin{tabular}{|c|c|c|c|c|}
\hline $\begin{array}{l}\text { Author, } \\
\text { year }\end{array}$ & $\begin{array}{l}\text { Criteria } \\
\text { Pedro } \\
\text { scale }\end{array}$ & Subjects & Intervention & Findings \\
\hline $\begin{array}{l}\text { Finucane e } \\
\text { Merce (32) }\end{array}$ & $5 / 11$ & $\begin{array}{l}13 \text { individuals with MDD } \\
\text { (03 male, } 10 \text { female) } \\
\text { (18 to } 65 \text { years old) } \\
\text { (ICD-10) }\end{array}$ & $\mathrm{GI}-{ }^{*} \mathrm{MBCT}$ & $\begin{array}{l}\text { Depression BDII Mean (SD) } \\
\text { Baseline to 8-week = 35.73(8.69) to } \\
17.82(14.59) \\
\text { Anxiety BAI Mean (SD) } \\
\text { Baseline to 8-week = 32.00(12.50) to } \\
20.51(17.08)\end{array}$ \\
\hline
\end{tabular}

(To be continued) 
Table 2 - Characteristics of the studies Interventions

\begin{tabular}{|c|c|c|c|c|}
\hline $\begin{array}{l}\text { Author, } \\
\text { year }\end{array}$ & $\begin{array}{l}\text { Criteria } \\
\text { Pedro } \\
\text { scale }\end{array}$ & Subjects & Intervention & Findings \\
\hline $\begin{array}{l}\text { Kenny e } \\
\text { Willians } \\
\text { (33) }\end{array}$ & $5 / 11$ & $\begin{array}{l}46 \text { individuals with MDD } \\
\text { (20 male, } 59 \text { female) } \\
\text { (17 to } 61 \text { years old) } \\
\text { (DSM-IV - SCID) } \\
\text { (patients who were currently } \\
\text { actively depressed, and } \\
\text { who had not responded fully } \\
\text { to standard treatments) }\end{array}$ & $\begin{array}{l}\mathrm{Gl} \text { - *MBCT } \\
\text { - moderate }(\mathrm{n}=26)(\mathrm{BDI} \leq 24) \text { and, } \\
\text { severe }(\mathrm{n}=29)(\mathrm{BDI} \geq 25) \\
\text { - With and Without thoughts of death } \\
\text { and suicide } \\
\text { - Homework involved around } 1 \mathrm{~h} \text { per } \\
\text { day of meditation or yoga, and other } \\
\text { related formal and informal practices } \\
\text { for the } 8 \text { weeks. }\end{array}$ & $\begin{array}{l}\text { BDI for suicidal Mean (SD) } \\
\text { - With thoughts of death and suicide } \\
=\text { Baseline to 8-week = 27.2(10.6) to } \\
\text { 14.8(10.6) } \\
\text { - Without thoughts of death and } \\
\text { suicide = Baseline to 8-week = } \\
\text { 20.2(5.7) to 12.8(7.8) } \\
\text { Depression BDI Mean (SD) p - } \\
\text { moderate (BDI } \leq 24)=\text { Baseline to } \\
\text { 8-week = 17.2(4.3) to 11.5(7.8) } \\
\text { - severe (BDI } \geq 25)=\text { Baseline to } \\
\text { 8-week = 33.2(6.4) to 17.1(11.2) } \\
\text { Total = Baseline to 8-week = } \\
\text { 24.39(9.8) to 13.9(9.7) p.00 }\end{array}$ \\
\hline $\begin{array}{l}\text { Barnhofer et } \\
\text { al. (34) }\end{array}$ & $5 / 11$ & $\begin{array}{l}28 \text { individuals with MDD } \\
\text { (19 female, } 9 \text { male) } \\
\text { (18 to } 65 \text { years old) } \\
\text { (DSM-IV - SCID) }\end{array}$ & $\begin{array}{l}\mathrm{GI}-(14){ }^{*} \mathrm{MBCT} \\
\mathrm{Gll}-(14) \mathrm{TAU}\end{array}$ & $\begin{array}{l}\text { Depression BDII Mean (SD) p } \\
\text { MBCT - Baseline to 8-week = } \\
29.36(9.66) \text { to } 17.62(10.94) \text { p.00 } \\
\text { TAU - Baseline to 8-week = } \\
31.32(10.79) \text { to } 28.86(12.97) \text { ns } \\
\text { Suicide Ideation BSS Mean (SD) } \\
\text { MBCT - Baseline to 8-week = } \\
2.21(2.45) \text { to 1.14(1.79) } \\
\text { TAU - Baseline to 8-week = } \\
2.78(2.08) \text { to 2.42(2.53) } \\
\text { Group did not meet criteria for a full } \\
\text { episode of Major Depression at post- } \\
\text { assessment } \\
\text { MBCT - 70\% } \\
\text { TAU - 18\% }\end{array}$ \\
\hline $\begin{array}{l}\text { Bondolfi et } \\
\text { al. (35) }\end{array}$ & $8 / 11$ & $\begin{array}{l}55 \text { individuals with MDD } \\
\text { ( } 43 \text { female, } 12 \text { male) } \\
\text { (18 to } 65 \text { years old) } \\
\text { (DSM-IV - SCID) } \\
\text { (limited the inclusion to } \\
\text { patients with } 3 \text { or more } \\
\text { previous episodes; least } \\
\text { three past depressive } \\
\text { episodes ( } 2 \text { episodes } \\
\text { in the past } 5 \text { years and } \\
\text { at least one in the past } \\
2 \text { years); remission } \\
\text { for at least } 3 \text { months } \\
\text { at time of enrolment; } \\
\text { history of treatment with } \\
\text { antidepressants but to } \\
\text { currently be off medication } \\
\text { for at least } 3 \text { months before } \\
\text { enrolment) }\end{array}$ & $\begin{array}{l}\mathrm{GI}-(27) * \mathrm{MBCT}+\mathrm{TAU} \\
\mathrm{Gll}-(28) \mathrm{TAU} \\
\text { Follow-up = } 14 \text { months }\end{array}$ & $\begin{array}{l}\text { Antidepressant medication was } \\
\text { reinstated in } \\
\text { MBCT +TAU - } 36 \% \\
\text { TAU- } 31 \% \\
\text { Time to relapse } \\
\text { MBCT + TAU - } 29 \text { weeks } \\
\text { TAU - } 10 \text { weeks } \\
\text { Delay until onset of antidepressant } \\
\text { medication } \\
\text { MBCT + TAU - } 204 \text { day } \\
\text { TAU - } 111 \text { day } \\
\text { One or more visit for counselling, } \\
\text { psychotherapy or support from } \\
\text { professional mental health staff was } \\
\text { undertaken } \\
\text { MBCT+TAU - } 46 \% \\
\text { TAU - } 55 \%\end{array}$ \\
\hline
\end{tabular}


Table 2 - Characteristics of the studies Interventions

\begin{tabular}{|c|c|c|c|c|}
\hline $\begin{array}{l}\text { Author, } \\
\text { year }\end{array}$ & $\begin{array}{l}\text { Criteria } \\
\text { Pedro } \\
\text { scale }\end{array}$ & Subjects & Intervention & Findings \\
\hline $\begin{array}{l}\text { Segal et al. } \\
(36)\end{array}$ & $9 / 11$ & $\begin{array}{l}84 \text { individuals with MDD } \\
\text { (48 female, } 36 \text { male) } \\
\text { (18 to } 65 \text { years old) } \\
\text { (DSM-IV - SCID) } \\
\text { (disorder with a minimum of } \\
2 \text { past episodes and } \geq 16 \\
\text { Hamilton Rating Scale for } \\
\text { Depression) }\end{array}$ & $\begin{array}{l}\text { GI - (28) m-ADM (To maintenance } \\
\text { antidepressant medication) } \\
\text { Gll - (26) *MBCT (To discontinuation } \\
\text { antidepressant medication + MBCT) } \\
\text { GIII - (30) PLA (To discontinuation } \\
\text { antidepressant medication + placebo } \\
\text { and clinical management) } \\
\text { (Patients in both the placebo and } \\
\text { MBCT conditions had their medication } \\
\text { tapered gradually, during a 4-week } \\
\text { period, via placebo substitution and } \\
\text { reduced pill count, respectively, at the } \\
\text { recommended rate for their specific } \\
\text { medication to minimize the risk of } \\
\text { discontinuation syndrome) } \\
\text { Follow-up = } 18 \text { months }\end{array}$ & $\begin{array}{l}\text { Rate of relapse } \\
\text { M-ADM - } 27 \% \\
\text { MBCT - } 28 \% \\
\text { PLA - } 71 \% \\
\text { Days to reach remission, mean (SD) } \\
\text { M-ADM - } 80.1(60.0) \\
\text { MBCT - } 68.1(51.9) \\
\text { PLA - } 90(57.8)\end{array}$ \\
\hline $\begin{array}{l}\text { Bieling et al. } \\
\text { (42) }\end{array}$ & $6 / 11$ & $\begin{array}{l}84 \text { individuals with MDD } \\
\text { ( } 52 \text { female, } 32 \text { male) } \\
\text { (18 to } 65 \text { years old) } \\
\text { (DSM-IV) }\end{array}$ & $\begin{array}{l}\text { GI - (28) ADM (To maintenance } \\
\text { antidepressant medication) } \\
\text { GII - (26) *MBCT (To discontinuation } \\
\text { antidepressant medication + MBCT) } \\
\text { GIII - (30) PLA (To discontinuation } \\
\text { antidepressant medication + placebo) } \\
\text { Follow-up = } 6 \text { months }\end{array}$ & $\begin{array}{l}\text { Rumination Mean (SD) } \\
\text { MBCT - Baseline to 8-week = } \\
17.40(4.10) \text { to } 17.73(3.91) \text { ns } \\
\text { ADM - Baseline to 8-week = } \\
\text { 19.12(2.20) to } 19.33(2.66) \text { ns } \\
\text { PLA - Baseline to 8-week = } \\
\text { 19.12(2.83) to } 19.05(3.36) \text { ns }\end{array}$ \\
\hline $\begin{array}{l}\text { Van Vugt et } \\
\text { al. (2) }\end{array}$ & $9 / 11$ & $\begin{array}{l}45 \text { individuals with MDD } \\
\text { ( } 39 \text { female, } 06 \text { male) } \\
\text { ( } 24 \text { to } 64 \text { years old) } \\
\text { (DSM-IV - SCID) } \\
\text { To maintenance } \\
\text { antidepressant medication }\end{array}$ & $\begin{array}{l}\mathrm{Gl}-(19) \text { control } \\
\mathrm{Gll}-(26){ }^{\star} \mathrm{MBCT}\end{array}$ & $\begin{array}{l}\text { Depression BDI Mean } p \\
\text { MBCT - Baseline to 8-week = 9.1 to } \\
6.5 \text { p.01 } \\
\text { Positive words (\%) } \\
\text { MBCT - Baseline to 8-week = } 28.9 \\
\text { to } 33.5 \\
\text { Control - Baseline to 8-week }=27.3 \\
\text { to } 30.5 \\
\text { Negative words (\%) } \\
\text { MBCT - Baseline to 8-week }=27.2 \% \\
\text { to } 27.4 \\
\text { Control - Baseline to 8-week }=24.0 \\
\text { to } 32.0 \\
\text { Anxiety (STAI-Y1) Mean (SD) } \\
\text { MBCT - Baseline to 8-week = } \\
\text { 53.4(10.9) p/ 50.7 (11.12) p.05 }\end{array}$ \\
\hline $\begin{array}{l}\text { Batink et al. } \\
\text { (43) }\end{array}$ & $8 / 11$ & $\begin{array}{l}130 \text { individuals with MDD } \\
\text { ( } 98 \text { female, } 32 \text { male) } \\
\text { (24 to } 64 \text { years old) } \\
\text { (DSM-IV - SCID) } \\
\text { To maintenance } \\
\text { antidepressant medication }\end{array}$ & $\begin{array}{l}\mathrm{GI}-(64) * \mathrm{MBCT}+\mathrm{TAU} \\
\text { Gll - (66) TAU } \\
\text { Randomization was stratified } \\
\text { according to number of depressive } \\
\text { episodes ( } \leq 2 \text { MDE vs } \geq 3 \mathrm{MDE} \text { ) }\end{array}$ & $\begin{array}{l}\text { Rumination Mean (SD) } \\
\text { MBCT + TAU- Baseline to 8-week = } \\
\leq 2-7.8(8.5) \text { to }-8.1(8.4) \text { ns } \\
\text { MBCT + TAU- Baseline to 8-week = } \\
\leq 3-7.8(8.5) \text { to }-7.5(8.8) \text { ns } \\
\text { TAU - Baseline to 8-week }=\leq 2 \\
-2.7(7.7) \text { to }-1.9(6.9) \text { ns } \\
\text { TAU - Baseline to 8-week }=\leq 3 \\
-2.7(7.7) \text { to }-3.7(8.6) \text { ns }\end{array}$ \\
\hline
\end{tabular}


Liberali R.

Table 2 - Characteristics of the studies Interventions

\begin{tabular}{|c|c|c|c|c|}
\hline $\begin{array}{l}\text { Author, } \\
\text { year }\end{array}$ & $\begin{array}{l}\text { Criteria } \\
\text { Pedro } \\
\text { scale }\end{array}$ & Subjects & Intervention & Findings \\
\hline $\begin{array}{l}\text { Munshi et } \\
\text { al. (37) }\end{array}$ & $5 / 11$ & $\begin{array}{l}18 \text { individuals with MDD } \\
\text { (13 female, } 05 \text { male) } \\
\text { (24 to } 81 \text { years old) } \\
\text { (DSM-IV - SCID) }\end{array}$ & $\begin{array}{l}\mathrm{Gl}-{ }^{*} \mathrm{MBCT} \\
\text { Follow-up }=48.7 \text { months }\end{array}$ & $\begin{array}{l}\text { Depression (BDI) Mean p } \\
\text { Baseline to } 8 \text {-week to follow-up - } 18.78 \\
\text { to } 5.33 \text { to } 5.89 \text { p.00 } \\
\text { Rumination (RRS) Mean } \\
\text { Baseline to } 8 \text {-week to follow-up - } \\
49.28 \text { to } 44.41 \text { to } 40.11 \text { p.00 } \\
\text { Anxiety (STAI-Y1) Mean } \\
\text { Baseline to 8-week to follow-up - } \\
44.22 \text { to } 31.56 \text { to } 31.22 \text { p.00 }\end{array}$ \\
\hline $\begin{array}{l}\text { Omidi et al. } \\
\text { (38) }\end{array}$ & $8 / 11$ & $\begin{array}{l}90 \text { individuals with MDD } \\
\text { ( } 60 \text { female, } 30 \text { male) } \\
\text { (18 to } 45 \text { years old) } \\
\text { (DSM-IV - SCID) }\end{array}$ & $\begin{array}{l}\text { GI - (30) *MBCT } \\
\text { GII - (30) CBT (traditional Cognitive } \\
\text { Behavior Therapy) } \\
\text { GIII - (30) TAU }\end{array}$ & $\begin{array}{l}\text { Depression (BSI) Mean (SD) } \\
\text { MBCT - Baseline to 8-week - } \\
2.05(0.84) \text { to 0.79(0.63) } \\
\text { CBT - Baseline to 8-week - } 2.18(0.57) \\
\text { to } 0.79(0.51) \\
\text { TAU - Baseline to 8-week - 2.18(0.85) } \\
\text { to } 1.96(0.86) \\
\text { Brief Symptom Inventory (BSI) Mean } \\
\text { (SD) } \\
\text { MBCT - Baseline to 8-week - } \\
\text { 1.62(0.56) to 0.72(0.46) } \\
\text { CBT - Baseline to 8-week - } 1.79(0.47) \\
\text { to 0.72(0.26) } \\
\text { TAU - Baseline to 8-week - } 1.79(0.50) \\
\text { to 1.59(0.52) }\end{array}$ \\
\hline $\begin{array}{l}\text { Schoenberg } \\
\text { e Speckens } \\
\text { (39) }\end{array}$ & $7 / 11$ & $\begin{array}{l}51 \text { individuals with MDD } \\
\text { (60 female, } 30 \text { male) } \\
\text { ( } 21 \text { to } 65 \text { years old) } \\
\text { (DSM-IV-TR) }\end{array}$ & $\begin{array}{l}\mathrm{GI}-(25) \text { control } \\
\mathrm{GII}-(26){ }^{*} \mathrm{MBCT}\end{array}$ & $\begin{array}{l}\text { Depression IDS Mean (SD)p } \\
\text { MBCT - Baseline to 8-week - 27.3(9.4) } \\
\text { to 19.3(9.3) p.02 } \\
\text { Control - Baseline to 8-week - } \\
\text { 25.1(12.3) to 25.3(13.2) ns } \\
\text { Response patterns towards feelings } \\
\text { of sadness/depression (RRS) Mean } \\
\text { (SD)p } \\
\text { MBCT - Baseline to 8-week - } \\
60.6(11.9) \text { to 55.1(11.0) p.03 } \\
\text { Control - Baseline to 8-week - } \\
60.2(13.2) \text { to 59.7(13.8) ns }\end{array}$ \\
\hline $\begin{array}{l}\text { Williams et } \\
\text { al. }(40)\end{array}$ & $6 / 11$ & $\begin{array}{l}255 \text { individuals with MDD } \\
\text { (198 female, } 57 \text { male) } \\
\text { ( } 18 \text { to } 70 \text { years old) } \\
\text { (DSM-IV - SCID and } \\
\text { suicidal feelings and at } \\
\text { least one other symptom of } \\
\text { depression, which together } \\
\text { were not attributable to } \\
\text { bereavement, substances, } \\
\text { or medical condition, but } \\
\text { were impairing functioning) }\end{array}$ & $\begin{array}{l}\text { GI - (99) *MBCT } \\
\text { Gll - (103) }{ }^{*} \text { CPE (cognitive } \\
\text { psychological education) } \\
\text { GIII - (53) TAU } \\
\text { Follow-up = } 6 \text { months }\end{array}$ & $\begin{array}{l}\text { Relapse to Major Depression (\%) } \\
\text { MBCT - } 46 \% \\
\text { CPE - } 50 \% \\
\text { TAU - } 53 \% \\
\text { Antidepressant use (\%) } \\
\text { MBCT - } 18 \% \\
\text { CPE - } 13 \% \\
\text { TAU - } 21 \% \\
\text { Looked for a psychiatrist (\%) } \\
\text { MBCT - } 10 \% \\
\text { CPE - } 9 \% \\
\text { TAU - } 11 \%\end{array}$ \\
\hline
\end{tabular}

(To be continued) 
Table 2 - Characteristics of the studies Interventions

(Conclusion)

\begin{tabular}{|c|c|c|c|c|}
\hline $\begin{array}{l}\text { Author, } \\
\text { year }\end{array}$ & $\begin{array}{l}\text { Criteria } \\
\text { Pedro } \\
\text { scale }\end{array}$ & Subjects & Intervention & Findings \\
\hline $\begin{array}{l}\text { Kuyken et } \\
\text { al. (41) }\end{array}$ & $10 / 11$ & $\begin{array}{l}424 \text { individuals with MDD } \\
\text { ( } 325 \text { female, } 99 \text { male) } \\
\text { (20 to } 79 \text { years old) }\end{array}$ & $\begin{array}{l}\text { GI }=(212) * \text { MBCT-TS }=\text { mindfulness } \\
+ \text { support to taper or discontinue } \\
\text { their maintenance antidepressant } \\
\text { medication } \\
\text { Gll }=(212) \text { m-ADM } \\
\text { Follow-up }=24 \text { months }\end{array}$ & $\begin{array}{l}\text { Depression BSII Mean (SD) } \\
\text { MBCT-TS } \\
\text { Baseline } 13.8(12.4) \text { to } 1 \text { month } \\
9.9(9.7) \text { to } 9 \text { months } 11.0(10 \cdot 5) \text { to } \\
12 \text { months } 10.7(10.0) \text { to } 18 \text { months } \\
11.7(10.6) \text { to } 24 \text { months } 11.6(10.9) \\
\text { ns } \\
\text { m-ADM } \\
\text { Baseline } 14.4(10.1) \text { to } 1 \text { month } \\
13.9(10.9) \text { to } 9 \text { months } 10.5(9.7) \text { to } \\
12 \text { months } 11.3(9.2) \text { to } 18 \text { months } \\
11.3(10.7) \text { to } 24 \text { months } 11.9(10.7) \\
\text { ns }\end{array}$ \\
\hline $\begin{array}{l}\text { Shallcross } \\
\text { et al. (13) }\end{array}$ & $8 / 11$ & $\begin{array}{l}51 \text { individuals with MDD } \\
\text { (38 female, } 13 \text { male) } \\
\text { (18 to } 65 \text { years old) } \\
\text { (DSM-IV - SCID) }\end{array}$ & $\begin{array}{l}\text { Gl }-(29){ }^{*} \mathrm{MBCT} \\
\text { Gll }-(22){ }^{* * A C C} \text { active control } \\
\text { condition } \\
\text { Follow-up = } 12 \text { months }\end{array}$ & $\begin{array}{l}\text { Depression BDII Mean (SD) } \\
\text { MBCT } \\
\text { Baseline } 12.1(7.5) \text { to } 1 \text { month } \\
11.9(7.2) \text { to } 6 \text { months } 8.2(6.9) \text { to } 12 \\
\text { months } 7.0(6.1) \\
\text { ACC } \\
\text { Baseline } 11.9(6.6) \text { to } 1 \text { month } 7.1(6.4) \\
\text { to } 6 \text { months } 6.2(5.7) \text { to } 12 \text { months } \\
7.2(6.0) \\
\text { Relapse to Major Depression } \\
\text { MBCT - 32.6\% } \\
\text { ACC - 30.4\% } \\
\text { Antidepressant use } \\
\text { MBCT Baseline } 30.4 \text { to } 1 \text { month } 28,1 \\
\text { ACC Baseline } 26.1 \text { to } 1 \text { month } 22.2\end{array}$ \\
\hline
\end{tabular}

Note: MBCT = Mindfulness-Based Cognitive Therapy; TAU = treatment-as-usual; MDD = Major depressive disorder; $\mathrm{m}$-ADM or ADM= Maintenance Antidepressant Medication; PLA = placebo; CBT = Traditional Cognitive Behavior Therapy; DSM-IV (Diagnostic and Statistical Manual of Mental Disorders (SCID));

*MBCT = Kabat-Zinn's (19) original 8-week program, weekly 2-hr sessions. Eight 2-h classes were held, up to an hour of which is spent in meditation practices. (body scan, sitting meditation, mindful movements, and 3-minute breathing space). MBCT sessions focus on cultivating mindfulness or nonjudgmental present-moment awareness of mental content and everyday activities. Exercises featuring: (1) guided (taped) awareness exercises directed at increasing moment-by-moment nonjudgmental awareness of bodily sensations, thoughts, and feelings; (2) accepting difficulties with a stance of self-compassion; (3) developing an "action plan" composed of strategies for responding to early warning signs of relapse/recurrence and (4) homework.

${ }^{* *} \mathrm{CPE}$ (cognitive psychological education) Comprised all elements of the MBCT program except the experiential cultivation of mindfulness through meditation practice and followed the same format of eight weekly 2-hr classes (i.e., matched for time with MBCT), with follow-up classes at 6 weeks and 6 months. Thus, participants learned about the psychological processes of relapse and were encouraged to apply what they had learned outside the sessions, to help prevent relapse. They also learned how to recognize the warning signs of depression and the importance of disengaging from unhelpful processes such as rumination and experiential avoidance. CPE educated them about these processes through interactive practical exercises and group discussions.

***ACC (active control condition) Based on the validated and manualized Health Enhancement Program (HEP). It included classes in four therapeutic components including physical activity, functional movement, music therapy, and nutrition, each of which lacked a mindfulness element. In-class time (weekly classes lasted $2.5 \mathrm{hr}$ for 8 weeks), group size (10 -12 participants in each group), and time outside of class for homework (approximately 50 min per day). 
Four studies presented continuous data $(13,34$, 39,41 ) and were classified for the performance of the meta-analysis (Figures 2 and 3). The metaanalysis showed a result that revealed a moderate effect of MBCT on the depression outcome with a significant effect estimation of -0.52 (95\% CI: -1.050 to $-0.002 ; \mathrm{p}=0.04)$, revealing differences between the interventions.

It should be noted that the $95 \% \mathrm{CI}$ of three articles and the diamond of the graph did not cross the statistically null line, indicating favorable results for MBCT regarding the depression scores, with only one study showing favorable results for the intervention (ACC $=$ active control condition). The analysis of heterogeneity showed a heterogeneous sample with $\mathrm{p}$ value of 0.04 for the $\mathrm{Q}$ test and $\mathrm{I} 2=77 \%$.

The result of effect size (ES) for the studies were: large effect size for the study of Barnhofer et al. (34) ( $d=0.93$, IC 95\%: 0.15 a 1.71), followed by that of Schoenberg and Speckens (39), with a medium ES ( $d=0.52$, IC $95 \%$ : -0.03 a 1.08$)$, and small ES for that of Kuyken et al. (41) ( $d=0.38$, IC 95\%: -0.36 a 1.13 ) and Shallcross et al. (13) $(\mathrm{d}=-0.26$, IC $95 \%$ : -0.81 a 0.29$)$.

\begin{tabular}{|c|c|c|c|c|c|c|c|}
\hline Study & $\mathbf{n}$ & $\begin{array}{l}\text { MBCT Mean } \\
\text { (SD) }\end{array}$ & $\mathrm{n}$ & $\begin{array}{l}\text { Control* } \\
\text { Mean (SD) }\end{array}$ & $\begin{array}{l}\text { Weight } \\
\text { (\%) }\end{array}$ & $\begin{array}{c}\text { Std mean } \\
\text { diference IV, } \\
\text { Random, } 95 \% \mathrm{Cl}\end{array}$ & $\begin{array}{l}\text { Std mean diference IV, } \\
\text { Random, } 95 \% \mathrm{CI}\end{array}$ \\
\hline 1 Barnhofer et al. (34) & 14 & $17.62(10.94)$ & 14 & $28.86(12.97)$ & 17.42 & $-1.77(-0.65,-0.88)$ & $\longleftarrow \cdot$ \\
\hline 2 Schoenberg e Speckens (39) & 26 & $19.3(9.3)$ & 25 & $25.3(13.2)$ & 24.77 & $-0.52(-1.08,0.03)$ & \\
\hline 3 Kuyken et al. (41) & 212 & $9.9(9.7)$ & 212 & $13.9(10.9)$ & 35.95 & $-0.38(-0.58,-0.19)$ & - \\
\hline 4 Shallcross et al. (13) & 29 & $8.9(7.2)$ & 22 & $7.1(6.4)$ & 24.86 & $0.16(-0.39,0.72)$ & \\
\hline Total (95\% IC) & 281 & & 273 & & 100.00 & $-0.52(-1.05,-0.00)$ & \\
\hline \multicolumn{8}{|c|}{$\begin{array}{l}\text { Heterogeneity } \text { Chi }^{2}=13.43, \text { df }=3(P=0.004) I^{2}=77.7 \% \\
\text { Tau-squared }=0.2073 \\
\text { Test for overall effect } Z=1.97(P=0.049)\end{array}$} \\
\hline
\end{tabular}

Note: ${ }^{\star}$ Control: 1 TAU Treatment as Usual, 2 Control, 3 m-ADM = Maintenance Antidepressant Medication, 4 ACC = active control condition; $\mathrm{Cl}=$ confidence intervals.

Figure 2 - Meta-analysis of studies evaluating effects of MBCT on depression.

In analyzing the studies of Barnhofer et al. (34) and Shallcross et al. (13) (Figure 2) differences were observed that could generate bias (sample and publication) compared with the results of the other studies. Therefore an additional analysis of sensitivity was performed, replicating the meta-analysis after excluding these two studies. The effect of MBCT on the depression scores remained, with a mean difference of -0.40 (95\% CI: -0.58 to $-0.03 ; \mathrm{p}=0.00$ ), with a lack of heterogeneity, according to the analysis using the $\mathrm{Q}$ test $(\mathrm{p}=0.64)$, with $\mathrm{I} 2=0 \%$ (Figure 3).

\begin{tabular}{|c|c|c|c|c|c|c|c|}
\hline Study & $n$ & $\begin{array}{c}\text { MBCT } \\
\text { Mean (SD) }\end{array}$ & $\mathrm{n}$ & $\begin{array}{l}\text { Control* } \\
\text { Mean (SD) }\end{array}$ & $\begin{array}{l}\text { Weight } \\
\text { (\%) }\end{array}$ & $\begin{array}{c}\text { Std mean } \\
\text { diference IV, } \\
\text { Random, } 95 \% \mathrm{Cl}\end{array}$ & $\begin{array}{l}\text { Std mean diference IV, } \\
\text { Random, } 95 \% \mathrm{Cl}\end{array}$ \\
\hline 2 Schoenberg e Speckens (39) & 26 & $19.3(9.3)$ & 25 & $25.3(13.2)$ & 24.77 & $-0.52(-1.08,0.03)$ & $\leftarrow$ \\
\hline 3 Kuyken et al. (41) & 212 & $9.9(9.7)$ & 212 & $13.9(10.9)$ & 35.95 & $-0.38(-0.58,-0.19)$ & \\
\hline Total (95\% IC) & 238 & & 237 & & 100.00 & $-0,40(-0.58,-0.22)$ & \\
\hline \multicolumn{8}{|c|}{$\begin{array}{l}\text { Teste heterogeneidade: } \mathrm{Chi}^{2}=0.21, \mathrm{df}=1(\mathrm{P}=0.64) \mathrm{I}^{2}=0 \% \\
\text { Tau-squared }=0,000 \\
\text { Estimativa de efeito: } \mathrm{Z}=4.34(\mathrm{P}=0.000)\end{array}$} \\
\hline
\end{tabular}

Note: *Control: 1 TAU Treatment as Usual, 2 Control, 3 m-ADM = Maintenance Antidepressant Medication, 4 ACC = active control condition; $\mathrm{Cl}=$ confidence intervals.

Figure 3 - Forest plot showing effects of MBCT on depression. 


\section{Discussion}

The results of a systematic review and metaanalysis (random effects model) and of the other studies (randomized and non-randomized studies) indicate that MBCT is likely to reduce depressive symptoms compared to the other treatments (control, TAU, ADM) and was shown to be equivalent to the ACC, in the improvement of scores of depression, anxiety, rumination and positive thoughts and words, among others.

It is assumed that, with the improvement of a symptom of depression, there is a tendency for improvement of various other symptoms together. In this review it was chosen to highlight some of these symptoms and their relationships with others, which could provide subsidies for understanding the treatment of individuals with MDD.

Firstly, the reduction of rumination and negative thoughts and the increase in sustaining trains of positive words were shown in two studies, with the effect in both the MBCT and the Control groups $(2,33)$. Both associated results are important in the treatment of MDD, as rumination is a persistent symptom and, although the content of rumination is typically negative, it is the persistent style (not content) of thought which is the central key to rumination, causing the person to have difficulties in attention and cognition $(44,45)$.

Desire is considered a component of human existence and desire and attachment are seen as the root of human suffering in Buddhist philosophy (46). From the cognitive perspective, desire reflects information processing and is rooted in cognitive processes (e.g. memory, expectations) (47).

Thus the practice of MBCT is beneficial to these symptoms, as it combines cognitive therapy with intensive training in meditation (48), focusing on observation and working on cognitive and affective processes. It teaches individuals to become more aware and to relate to themselves (49), helping to eliminate the patterns of rumination and negative thoughts that can contribute to relapse, bringing awareness to the experience of desire, teaching the subjects to observe without reacting or judging, and to avoid suffering (50).

The regular practice of MBCT increases the thickness of the cortex in the areas of the somatosensory system, which is positively correlated with increased awareness of the body (51). It also leads individuals to accept experience as impermanent, recognizing that neither the positive state nor the negative state are long lasting and allowing them to realize that the effort exerted to achieve or hold on to a certain state of being is not only useless, but can cause suffering (52).

The positive relationship between the practice of MBCT and improvement in depressive symptoms is consistent with several other studies. Petrocchis and Ottaviani (53) showed decreased rumination and increased positive thoughts mediated by the impact of non-judgment, with 41 subjects, in a longitudinal study of up to 2 years of practice. Schroevers and Brandsma (54) found improvements in positive attitudes (feeling enthusiastic and active) and decreases in negative attitudes (negative mood, anger, sadness and nervousness), with 64 individuals, in eight weeks of practice. Sephton et al. (55) reported decreased use of antidepressants, pain, improvements in the symptoms of depression and in sleep, with 91 women with fibromyalgia, after 8 weeks of practice.

Secondly, another result that should be mentioned is the higher number of women in the samples compared to men. It is assumed that some risk factors may be triggering MDD, such as biological aspects, hormonal fluctuations during the reproductive period, menopause and psychosocial aspects (social and family roles) in women and sexual abuse in childhood, behavior disorder, drug abuse and stressful life events (mainly financial and professional problems) in men $(56,57)$.

Women with MDD are more prone to anxiety disorder and suicide ideation while men show more agitation, substance abuse and if prone to suicide tend to be successful (58). In the present review, two studies showed decreased suicidal tendencies, with MBCT proving better than TAU in both. Hargus et al. (59) studied 27 depressed individuals with suicidal crises or warning signs for their last crisis and observed that the MCBT group obtained better results than the TAU group, as it caused individuals to reflect on the previous crises in a detailed and decentralized way, allowing them to relate to these experiences.

Thirdly, many of the selected studies made comparisons between MBCT and other therapeutic interventions. What may differentiate MBCT from other therapies is that, despite perception and attention being constant features of normal body functioning, MBCT aims to raise awareness by improving the perception and attention in the current reality (60).

In this review, MBCT was shown to be better when compared with TAU for various depressive symptoms, for rate and time of relapse and for the time of seeking a psychotherapist. In only one study MBCT and ADM 
were found to be equivalent. Kuykem et al. (41) showed similar results between the two regarding relapse rate and days of remission. Greater improvements in depressive symptoms compared with TAU has also been observed in other studies, such as that of Godfrin and Van Heeringen (61) with 106 depressed individuals, after 56 weeks, where they observed reductions in the time and rate of relapse and in the depressive mood and improvements in the quality life in the MBCT + TAU group, compared to the TAU only group.

Two interventions (ACC e CPE) showed a trend of better results than the practice of MBCT, in the use of antidepressants, in seeking a psychotherapist and in the relapse rate in patients with MDD. It should be highlighted that both therapeutic interventions resembled MBCT, because ACC uses the elements of MBCT with increased physical exercise, functional movements, music therapy and nutrition. Cognitive psychological education, as in MBCT, uses interactive practical exercises and group discussions to teach individuals about the psychological processes of relapses, monitoring of the mood, the importance of recognizing the various elements of the experience (thoughts, emotions, feelings and behavior) and to switch off negative aspects, such as rumination (62).

In this review, one study showed that CBT presented results similar to MBCT, with the improvement of the general symptoms of depression. The study of Manicavasgar, Parker and Perich (63), which compared MCBT to CBT, also showed the same results regarding the symptoms of depression. This can be explained because CBT incorporates aspects of meditation added to the monitoring of thought, identification of cognitive distortions, self-esteem, goal setting and the identification of problems and supports (64). Cladder-Micus et al. (65) highlighted that this union is important because MBCT develops self-compassion and focuses on the process of thinking, while CBT focuses on the content of the thoughts.

Some limitations of this meta-analysis should be considered. The first is the quality of the studies (Table 1), not always achieving top marks in the Pedro scale. The second is that some studies did not report basic data of the descriptive and inferential statistics, presenting only frequency values. Thirdly, non-randomized clinical trials were included and the meta-analysis of these studies was not performed. This choice was due to the need observed in the literature for an article that also presented innovative results even though not carried out randomly. Fourthly, choosing the articles from just one database may have lead to the absence of intervention studies with excellent quality accepted in other databases. This choice was made because this database is freely accessible and has quality in its publications.

\section{Conclusion}

This systematic review and meta-analysis suggests that MBCT can be considered a promising alternative for the treatment of MDD. The results show that MBCT alone is effective for the main symptoms of MDD, however, when integrated with other cognitive interventions (TAU ACC, CPE, CBT) and with the use of medications (ADM) it is shown to be more effective. These findings demonstrate the need for greater provision of alternative treatments for MDD, which would reduce intervention costs and could increase the coverage.

\section{References}

1. Skodol AE, Grilo CM, Keyes KM, Geier T, Grant BF, Hasin DS. Relationship of personality disorders to the course of major depressive disorder in a nationally representative sample. Am J Psychiatry. 2011;168(3):257-64.

2. Van Vugt MK, Hitchcock P, Shahar B, Britton W. The effects of mindfulness-based cognitive therapy on affective memory recall dynamics in depression: a mechanistic model of rumination. Front Hum Neurosci. 2012;6:257.

3. Hankerson SH, Fenton MC, Geier TJ, Keyes KM, Weissman MM, Hasin DS. Racial differences in symptoms, comorbidity, and treatment for major depressive disorder among black and white adults. J Natl Med Assoc. 2011;103(7):576-84.

4. Bielczyk NZ, Buitelaar JK, Glennon JC, Tiesinga PH. Circuit to construct mapping: a mathematical tool for assisting the diagnosis and treatment in major depressive disorder. Front Psychiatry. 2015;6:29.

5. Han C, Wang SM, Lee SJ, Jun TY, Pae CU. Optimizing the use of aripiprazole augmentation in the treatment of major depressive disorder: from clinical trials to clinical practice. Chonnam Med J. 2015;51(2):66-80. 
6. Kinyanda E, Hoskins S, Nakku J, Nawaz S, Patel V. Prevalence and risk factors of major depressive disorder in HIV/AIDS as seen in semi-urban Entebbe district, Uganda. BMC Psychiatry. 2011;11:205.

7. Pradhan B, Parikh T, Makani R, Sahoo M. Ketamine, Transcranial Magnetic Stimulation, and Depression Specific Yoga and Mindfulness Based Cognitive Therapy in Management of Treatment Resistant Depression: Review and Some Data on Efficacy. Depress Res Treat. 2015;2015:842817.

8. Thaipisuttikul P, Ittasakul P, Waleeprakhon P, Wisajun P, Jullagate S. Psychiatric comorbidities in patients with major depressive disorder. Neuropsychiatr Dis Treat. 2014;10:2097-103.

9. Bio DS, Souza EL, Moreno RA. Remissão sintomática e qualidade de vida em pacientes com depressão maior tratados com antidepressivo: um estudo prospectivo. Aletheia. 2011;(34):151-62.

10. Manoliu A, Meng C, Brandl F, Doll A, Tahmasian M, Scherr M. et al. Insular dysfunction within the salience network is associated with severity of symptoms and aberrant inter-network connectivity in major depressive disorder. Front Hum Neurosci. 2014;7:930.

11. Wilson S, Vaidyanathan U, Miller MB, McGue M, Iacono WG. Premorbid risk factors for major depressive disorder: are they associated with early onset and recurrent course? Dev Psychopathol. 2014;26(4 Pt 2):1477-93.

12. Cipriani A, Purgato M, Furukawa TA, Trespidi C, Imperadore G, Signoretti A, et al. Citalopram versus other anti-depressive agents for depression. Cochrane Database Syst Rev. 2012;(7):CD006534.

13. Shallcross AJ, Gross JJ, Visvanathan PD, Kumar N, Palfrey A, Ford BQ, et al. Relapse prevention in major depressive disorder: mindfulnessbased cognitive therapy versus an active control condition. J Consult Clin Psychol. 2015;83(5):964-75.

14. Stahl ST, Albert SM, Dew MA, Lockovich MH, Reynolds CF. Coaching in healthy dietary practices in at-risk older adults: a case of indicated depression prevention. Am J Psychiatry. 2014;171(5):499-505.

15. Salmon P, Sephton S, Weissbecker I, Hoover K, Ulmer C, Studts JL. Mindfulness meditation in clinical practice. Cogn Behav Pract. 2004;11(4):434-46.
16. Ospina MB, Bond TK, Karkhaneh M, Tjosvold L, Vandermeer B, Liang Y, et al. Meditation practices for health: state of the research. Evid Rep Technol Assess (Full Rep). 2007;(155):1-263.

17. Baer RA. Mindfulness training as a clinical intervention: a conceptual and empirical review. Clin Psychol. 2003;10(2):125-43.

18. Grossman P, Niemann L, Schmidt S, Walach H. Mindfulness-based stress reduction and health benefits. A meta-analysis. J Psychosom Res. 2004;57(1):35-43.

19. Kabat-Zinn J. Full catastrophe living: using the wisdom of your body and mind to face stress, pain, and illness. New York: Delta; 1990.

20. Santorelli SF, editor. Mindfulness-based stress reduction (MBSR): standards of practice. The Center for Mindfulness in Medicine, Health Care, and Society University of Massachusetts Medical School. Center for Mindfulness in Medicine, Health Care \& Society, Department of Medicine, Division of Preventive and Behavioral Medicine; 2014.

21. Vago DR, Silbersweig DA. Self-awareness, self-regulation, and self-transcendence (S-ART): a framework for understanding the neurobiological mechanisms of mindfulness. Front Hum Neurosci. 2012;6:296.

22. Crane RS, Kuyken W, Hastings RP, Rothwell N, Williams JM. Training Teachers to Deliver Mindfulness-Based Interventions: Learning from the UK Experience. Mindfulness (N Y). 2010;1(2):74-86.

23. Britton WB, Shahar B, Szepsenwol O, Jacobs WJ. Mindfulness-based cognitive therapy improves emotional reactivity to social stress: results from a randomized controlled trial. Behav Ther. 2012;43(2):365-80.

24. Rycroft-Malone J, Anderson R, Crane RS, Gibson A, Gradinger F, Griffiths HO. Accessibility and Implementation in UK Services of an Effective Depression Relapse Prevention Programme Mindfulness-Based Cognitive Therapy (MBCT): ASPIRE Study Protocol. Implement Sci. 2014;9:62.

25. National Collaborating Centre for Mental Health (UK). Depression: The Treatment and Management of Depression in Adults (Updated Edition). NICE Clinical Guidelines, No. 90. Leicester (UK): British Psychological Society; 2010 [cited 2015 Nov 10]. Available from: https://tinyurl.com/znnonhn. 
26. Schoultz M, Atherton I, Watson A. Mindfulnessbased cognitive therapy for inflammatory bowel disease patients: findings from an exploratory pilot randomised controlled trial. Trials. 2015;16:379.

27. Zeidan F, Grant JA, Brown CA, McHaffie JG, Coghill RC. Mindfulness meditation-related pain relief: evidence for unique brain mechanisms in the regulation of pain. Neurosci Lett. 2012;520(2):165-73.

28. Cook D, West CP. Conducting systematic reviews in medical education: a stepwise approach. Med Educ. 2012;46(10):943-52.

29. PEDro. Physiotherapy Evidence Database [cited 2015 Nov 7]. Available from: https://www.pedro.org.au.

30. Higgins JP, Thompson SG, Deeks JJ, Altman DG. Measuring inconsistency in meta-analyses. BMJ. 2003;327(7414):557-60.

31. Cohen J. Statistical power analysis for the behavioral sciences. Hillsdale, NJ: Lawrence Erlbaum Associates; 1988.

32. Finucane A, Mercer SW. An exploratory mixed methods study of the acceptability and effectiveness of Mindfulness-Based Cognitive Therapy for patients with active depression and anxiety in primary care. BMC Psychiatry. 2006;6:14.

33. Kenny MA, Williams JM. Treatment-resistant depressed patients show a good response to Mindfulness-based Cognitive Therapy. Behav Res Ther. 2007;45(3):617-25.

34. Barnhofer T, Crane C, Hargus E, Amarasinghe M, Winder R, Williams JM. Mindfulness-based cognitive therapy as a treatment for chronic depression: A preliminary study. Behav Res Ther. 2009;47(5):366-73.

35. Bondolfi G, Jermann F, der Linden MV, Gex-Fabry M, Bizzini L, Rouget BW, et al. Depression Relapse prophylaxis with Mindfulness-Based Cognitive Therapy: replication and extension in the Swiss health care system. J Affect Disord. 2010;122(3):224-31.

36. Segal ZV, Bieling P, Young T, MacQueen G, Cooke R, Martin L, et al. Antidepressant monotherapy vs sequential pharmacotherapy and mindfulness-based cognitive therapy, or placebo, for relapse prophylaxis in recurrent depression. Arch Gen Psychiatry. 2010;67(12):1256-64.
37. Munshi K, Eisendrath S, Delucchi K. Preliminary long-term follow-up of Mindfulness-based cognitive therapy-induced remission of depression. Mindfulness (N Y). 2013;4(4):354-61.

38. Omidi A, Mohammadkhani P, Mohammadi A, Zargar F. Comparing mindfulness based cognitive therapy and traditional cognitive behavior therapy with treatments as usual on reduction of major depressive disorder symptoms. Iran Red Crescent Med J. 2013;15(2):142-6.

39. Schoenberg PL, Speckens AE. Modulation of induced frontocentral theta (Fm- $\theta$ ) event-related (de-) synchronisation dynamics following mindfulnessbased cognitive therapy in Major Depressive Disorder. Cogn Neurodyn. 2014;8(5):373-88.

40. Willians JM, Crane C, Barnhofer T, Brennan $\mathrm{K}$, Duggan DS, Fennell MJ, et al. Mindfulness-based cognitive therapy for preventive relapse in recurrent depression: a randomized dismantling trial. J Consult Clin Psychol. 2014;82(2):275-86.

41. Kuyken W, Hayes R, Barrett B, Byng R, Dalgleish T, Kessler D, et al. Effectiveness and cost-effectiveness of mindfulness-based cognitive therapy compared with maintenance antidepressant treatment in the prevention of depressive relapse or recurrence (PREVENT): a randomised controlled trial. Lancet. 2015;386(9988):63-73.

42. 42 - Bieling PJ, Hawley LL, Bloch RT, Corcoran KM, Levitan RD, Young L, et al. Treatment-specific changes in decentering following mindfulness-based cognitive therapy versus antidepressant medication or placebo for prevention of depressive relapse. J Consult Clin Psychol. 2012;80(3):365-72.

43. Batink T, Peeters F, Geschwind N, van Os J, Wichers M. How does MBCT for depression work? Studying cognitive and affective mediation pathways. PLoS One. 2013;8(8):e72778.

44. Onraedt T, Koster EH. Training Working Memory to Reduce Rumination. PLoS One. 2014;9(3):e90632.

45. Wagner CA, Alloy LB, Abramson LY. Trait rumination, depression, and executive functions in early adolescence. J Youth Adolesc. 2015;44(1):18-36.

46. 46 - Lama D, Bhikkhu B (Editor). In the Buddha's words: An anthology of Discourses from the Pali Canon (The Teachings of the Buddha). Somerville, MA: Wisdom Publications; 2005. 
47. Tiffany ST. Cognitive concepts of craving. Alcohol Res Health. 1999;23(3):215-24.

48. Crane C, Williams JM. Factors Associated with Attrition from Mindfulness-Based Cognitive Therapy in Patients with a History of Suicidal Depression. Mindfulness (N Y). 2010;1(1):10-20.

49. van der Velden AM, Kuyken W, Wattar U, Crane C, Pallesen KJ, Dahlgaard J, et al. A systematic review of mechanisms of change in mindfulness-based cognitive therapy in the treatment of recurrent major depressive disorder. Clin Psychol Rev. 2015;37:26-39.

50. Xie JF, Zhou JD, Gong LN, Iennaco JDS, Ding SQ. Mindfulness-based cognitive therapy in the intervention of psychiatric disorders: A review. IJNSS. 2014;1(2):232-9.

51. Braboszcz C, Hahusseau S, Delorme A. Meditation and Neuroscience: from basic research to clinical practice. In: Carlstedt RA (Ed). Integrative Clinical Psychology, Psychiatry and Behavioral Medicine: Perspectives, Practices and Research. New York: Springer Publishing; 2010.

52. Witkiewitz K, Bowen S, Douglas H, Hsu SH. Mindfulness-based relapse prevention for substance craving. Addict Behav. 2013;38(2):1563-71.

53. Petrocchi N, Ottaviani C. Mindfulness facets distinctively predict depressive symptoms after two years: The mediating role of rumination. Pers Individ Dif. 2016;93:92-6.

54. Schroevers MJ, Brandsma R. Is learning mindfulness associated with improved affect after mindfulnessbased cognitive therapy? Br J Psychol. 2010;101(Pt 1):95-107.

55. Sephton SE, Salmon P, Weissbecker I, Ulmer C, Floyd A, Hoover $\mathrm{K}$, et al. Mindfulness meditation alleviates depressive symptoms in women with fibromyalgia: results of a randomized clinical trial. Arthritis Rheum. 2007;57(1):77-85.

56. Kendler KS, Gardner CO. Sex differences in the pathways to major depression: a study of oppositesex twin pairs. Am J Psychiat. 2014;171(4):426-35.

57. Dessotte CAM, Silva FS, Furuya RK, Ciol MA, Hoffman JM, Dantas RAS. Sintomas depressivos somáticos e cognitivo-afetivos entre pacientes com doença cardíaca: diferenças por sexo e idade. Rev Latino-Am Enfermagem. 2015;23(2):208-15.
58. Kong L, Chen K, Womer F, Jiang W, Luo X, Driesen N, et al. Sex differences of gray matter morphology in corticolimbicstriatal neural system in major depressive disorder. J Psychiatr Res. 2013;47(6):733-9.

59. Hargus E, Crane C, Barnhofer T, Williams JM. Effects of mindfulness on meta-awareness and specificity of describing prodromal symptoms in suicidal depression. Emotion. 2010;10(1):34-42.

60. Brown KW, Ryan RM. The benefits of being present: mindfulness and its role in psychological wellbeing. J Pers Soc Psychol. 2003;84(4):822-48.

61. Godfrin KA, van Heeringen C. The effects of mindfulness-based cognitive therapy on recurrence of depressive episodes, mental health and quality of life: A randomized controlled study. Behav Res Ther. 2010;48(8):738-46.

62. Williams JM, Russell IT, Crane C, Russell D, Whitaker CJ, Duggan DS, et al. Staying well after depression: trial design and protocol. BMC Psychiatry. 2010;10:23.

63. Manicavasgar V, Parker G, Perich T. Mindfulness-based cognitive therapy vs cognitive behaviour therapy as a treatment for non-melancholic depression. J Affect Disord. 2011;130(1-2):138-44.

64. Walker ER, Obolensky N, Dini S, Thompson NJ. Formative and process evaluations of a cognitivebehavioral therapy and mindfulness intervention for people with epilepsy and depression. Epilepsy Behav. 2010;19(3):239-46.

65. Cladder-Micus MB, Vrijsen JN, Becker ES, Donders $\mathrm{R}$, Spijker J, Speckens AE. A randomized controlled trial of Mindfulness-Based Cognitive Therapy (MBCT) versus treatment-as-usual (TAU) for chronic, treatment-resistant depression: study protocol. BMC Psychiatry. 2015;15:275.
Received in 12/08/2015
Recebido em 08/12/2015

Approved in 11/21/2016

Aprovado em 21/11/2016 